\title{
Structural Investigations of Afghanistan Deduced from Remote Sensing and Potential Field Data
}

\author{
Hakim SAIBI ${ }^{1,2}$, Masood AZIZI ${ }^{1}$, and Saad MOGREN ${ }^{3}$ \\ ${ }^{1}$ Kyushu University, Faculty of Engineering, \\ Department of Earth Resources Engineering, Fukuoka, Japan; \\ e-mail: saibi-hakim@mine.kyushu-u.ac.jp (corresponding author) \\ ${ }^{2}$ Dept. of Geology, United Arab Emirates University, Al-Ain, United Arab Emirates \\ ${ }^{3}$ King Saud University, Department of Geology and Geophysics, \\ Riyadh, Saudi Arabia; e-mail: smogren@ksu.edu.sa
}

\begin{abstract}
This study integrates potential gravity and magnetic field data with remotely sensed images and geological data in an effort to understand the subsurface major geological structures in Afghanistan. Integrated analysis of Landsat SRTM data was applied for extraction of geological lineaments. The potential field data were analyzed using gradient interpretation techniques, such as analytic signal (AS), tilt derivative (TDR), horizontal gradient of the tilt derivative (HG-TDR), Euler Deconvolution (ED) and power spectrum methods, and results were correlated with known geological structures.

The analysis of remote sensing data and potential field data reveals the regional geological structural characteristics of Afghanistan. The power spectrum analysis of magnetic and gravity data suggests shallow basement rocks at around 1 to $1.5 \mathrm{~km}$ depth. The results of TDR of potential field data are in agreement with the location of the major regional fault structures and also the location of the basins and swells, except in the Helmand region (SW Afghanistan) where many high potential field anomalies are observed and attributed to batholiths and near-surface volcanic rocks intrusions.
\end{abstract}

Ownership: Institute of Geophysics, Polish Academy of Sciences;

(C) 2016 Saibi et al. This is an open access article distributed under the Creative Commons Attribution-NonCommercial-NoDerivs license,

http://creativecommons.org/licenses/by-nc-nd/3.0/. 
A high-resolution airborne geophysical survey in the data sparse region of eastern Afghanistan is recommended in order to have a complete image of the potential field anomalies.

Key words: gravity, magnetic, remote sensing; structure, Afghanistan.

\section{INTRODUCTION}

Regional interpretation and analysis of potential field data (gravity and aeromagnetic data) has been shown to be extremely effective tool to map geology in remote and inaccessible regions and areas buried by shallow cover (Betts et al. 2003, McLean et al. 2009, Aitken and Betts 2009). The technique is particularly effective for studies of the architecture character of the Earth's crust because the data is effective for interpreting 3D geometry of structure and geological bodies (Aitken and Betts 2009, Blaikie et al. 2014, Spampinato et al. 2015), overprinting relationships (Betts et al. 2003), and fault kinematics (Betts et al. 2007). The data is also sensitive to alteration associated with fluid-rock interactions, and igneous intrusions.

Afghanistan preserves some of the most complex and diverse geology in the world associated with the closure of Tethys and the peripherial responses to collision between India and Eurasia. The country is divided into many tectonic blocks bordered by deep-faults that formed or reactivated in response to this collision. These rocks are abundantly rich in natural resources (mineral, petroleum, and natural gas) but much of the Afghanistan's potential remains unknown. The nation is underexplored because it has suffered through decades of war, which affected the education and research progress in the country. Consequently, Afghanistan may represent one of the last bastions of untapped mineral and energy resources on the planet.

In 1966, a German geophysical firm carried out airborne magnetometer measurements in the southern part of Afghanistan in order to explore the depth of the sedimentary basins for oil exploration and possible location of ore bodies for mineral exploration (Bosum et al. 1968). The data covered the East Afghan Trough, Helmand, Rosgan, and Ghor basins, and southwestern Afghanistan.

Recently, the USGS started airborne geophysical surveys in cooperation with the Afghanistan Geological Survey (AGS) (USGS 2006, 2008), which covers almost the entire country except of eastern Afghanistan due to security reasons. Here, we present an interpretation of the recent potential field data provided by AGS.

The objective of this study is to delineate the subsurface structure of Afghanistan from the potential field and remote-sensing data. The interpretation techniques applied for the potential field data are tilt derivative (TDR), analytic signal (AS), horizontal derivative of the tilt derivative (HG-TDR), 
and Euler Deconvolution (ED). The combination of these methods enhanced the structural definition of Afghanistan. A power spectrum analysis is also performed for gravity and magnetic data in order to detect the depth to the gravity and magnetic sources in Afghanistan. The geophysical data were combined with geological and remote sensing data for better understanding of the subsurface structure to provide context for a wide variety of investigations, such as mineral and energy resources assessments, environmental characterizations, and groundwater studies.

Our approach has been effectively used to constrain the crustal architecture and geology of numerous areas including: Rabie and Ammar (1990), Kamel and Elsirafe (1994) in Egypt, Lunden et al. (2001) in Sweden, Lamontagne et al. (2003) in Canada, Chen and Zhou (2005) in China, Yassaghi (2006) in Iran, Saadi et al. (2008a, b) in Libya, Khamies and ElTarras (2010) in Egypt, Azizi and Saibi (2015) and Azizi et al. (2015) in Aynak-Logar valley, eastern Afghanistan.

The combination of the three types of data (geology, remote sensing, and potential field) is processed in Geographic Information System (GIS) using ArcGIS Ver. 10, ER Mapper Ver. 7.0, and ENVI Ver. 4.7. The geophysical data is processed using Geosoft Ver. 8.

\section{GEOLOGY, SEISMICITY, AND TECTONIC SETTINGS}

The color shaded relief map of Afghanistan and the surrounding area (Fig. 1) shows the large area of mountainous terrain in the country compared with the relative lowlands to the southwest. The relief map emphasizes that the mountain belt is not linear. This tectonic morphology is a direct result of the India-Asia collision to the east of Afghanistan.

The oldest rocks in Afghanistan are of Archean age and succeeded by rocks from the Precambrian up to the Quaternary (Fig. 2). The country has a complicated tectonic history due to its position at the western end of the Himalaya. Information on geology and tectonics of Afghanistan are discussed in detail by Schindler (2002), AGS (2005), and Wheeler et al. (2005).

The Arabian plate is moving northward with respect of Eurasian plate at $3.3 \mathrm{~cm} /$ year (Wheeler et al. 2005) and the Indian plate is subducting beneath the Eurasian plate with a rate of $3.9 \mathrm{~cm} /$ year (Jung et al. 2013) or faster (Wheeler et al. 2005). Consequently, Afghanistan remains extremely seismically active (Fig. 3) with earthquake activity mainly in and around northeastern Afghanistan (Hindu Kush and Pamirs).

Afghanistan can be split into four major tectonic regions: the accreted terranes in the south, the transpressional plate boundary in the east, the north Afghan platform in the north, and the Hindu Kush/Pamirs in the north-east. The high density of faults (Fig. 4) is mainly located along the Hari Rod Fault 


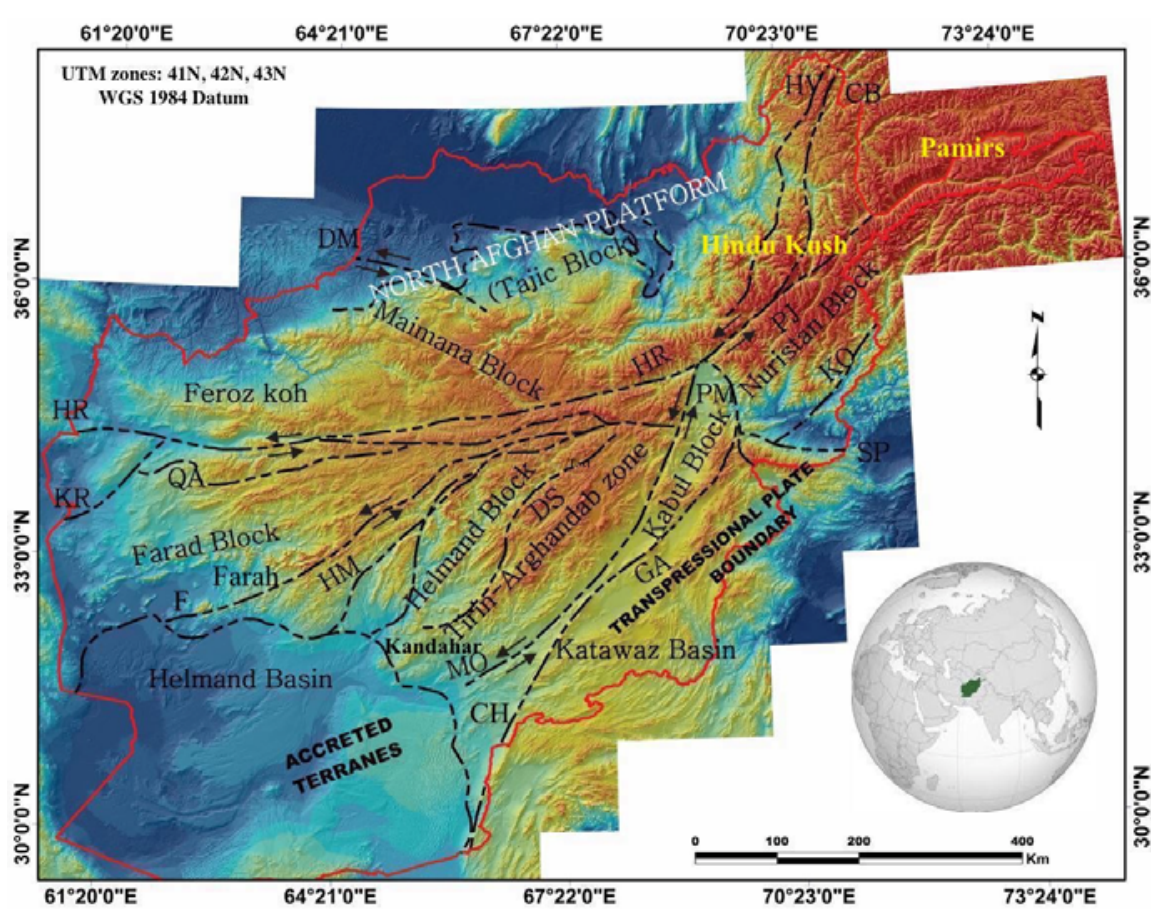

Fig. 1. Color shaded relief map of Afghanistan topography including tectonic block names and abbreviations of major faults: $\mathrm{CH}$ - Chaman, $\mathrm{CB}$ - Central Badakhsan, DS - Darafshan, DM - Dosi Mirzavalan, GA - Gardez, HR - Hari Rod, HM - Helmand, HV - Henjvan, KR - Kaj Rod, KO - Konar, MO - Mokur, PM - Paghman, PJ - Panjshir, QA - Qarghanaw, SP - Spinghar, F - Farah.
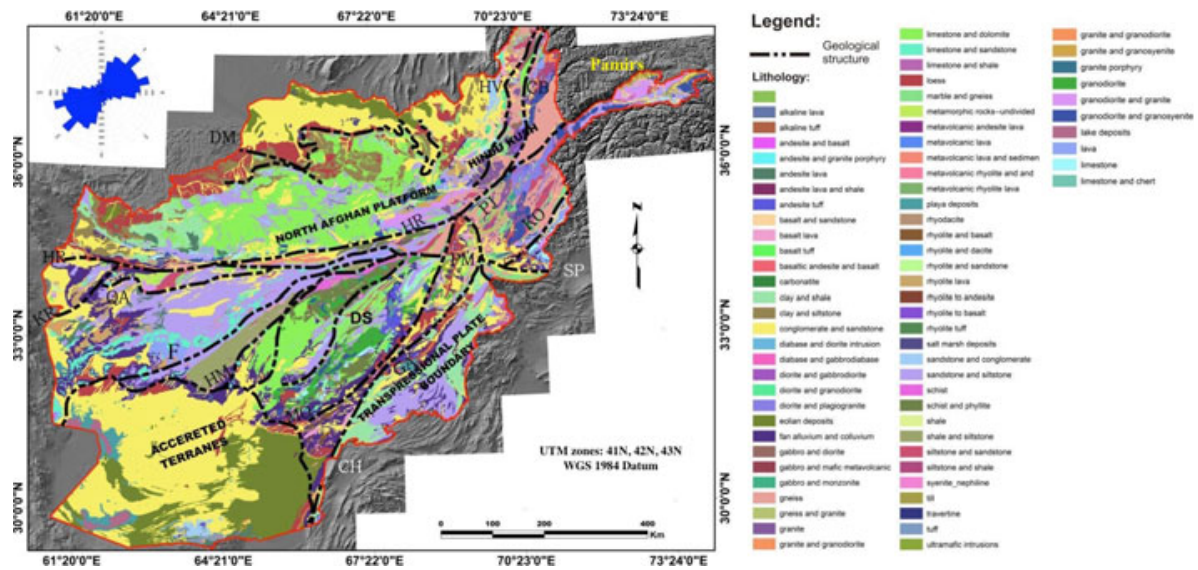

Fig. 2. Geological map showing rock units in Afghanistan and the locations of major faults (modified from Mihalasky et al. 2007), overlaid on the shaded relief (SRTM) map. 


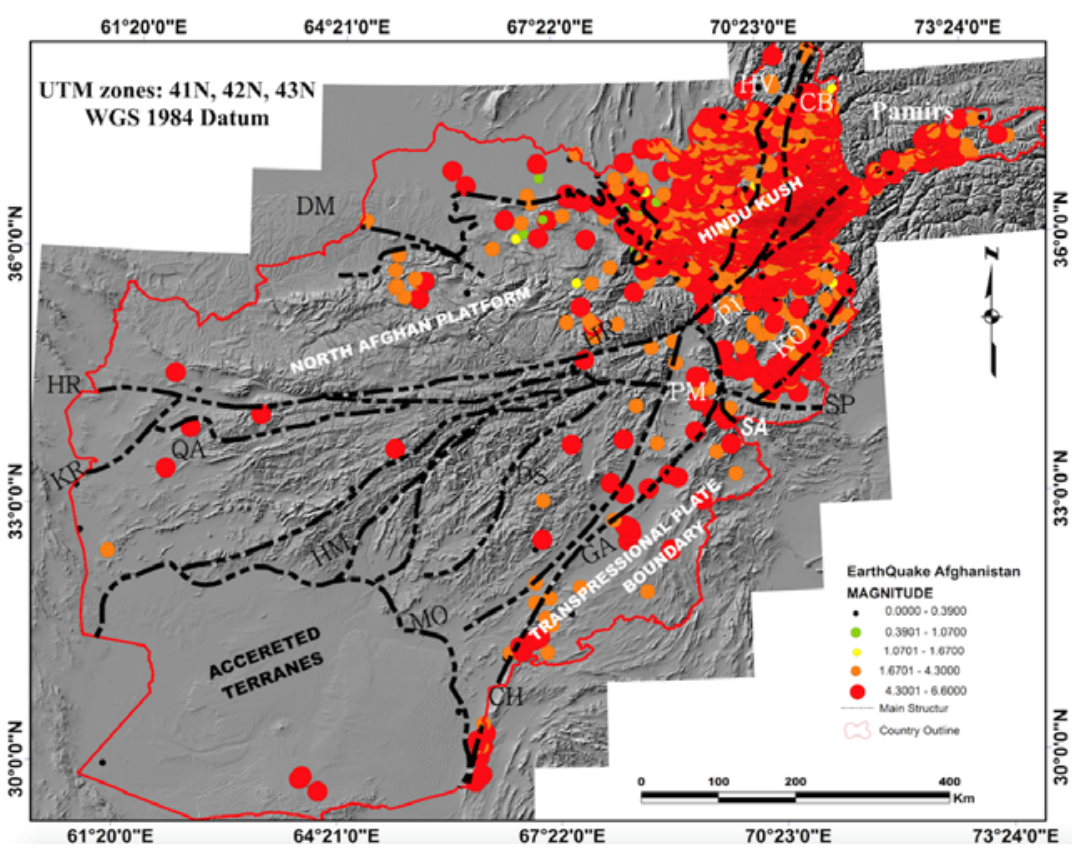

Fig. 3. Seismicity in Afghanistan.

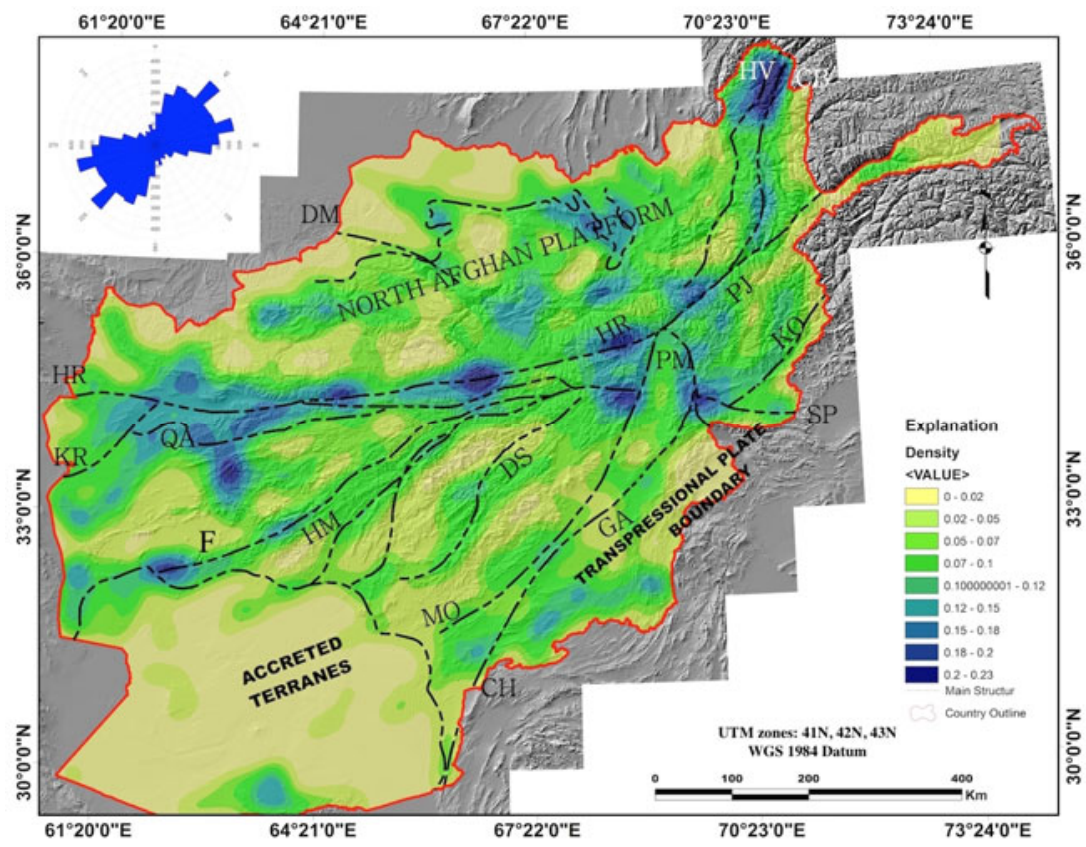

Fig. 4. Density map and rose diagram from known major geological faults in Afghanistan, overlaid on the shaded relief (SRTM) map. 
system. These faults are dominated by two orientations, NE-SW and ENEWSW (Fig. 4).

\section{REMOTE SENSING DATA}

Shuttle Radar Topography Mission (SRTM) images were prepared and interpreted to analyze geological structures in the study area. The SRTM obtained elevation data on a near-global scale to generate the most complete high-resolution digital topographic database of the Earth (Durga Rao et al. 2009). In this study, the $90 \mathrm{~m}$ resolution SRTM data were used to derive the topographic features of the study area. A series of landform interpretation experiments was conducted on the ETM+ images using contrast stretching methods and Hue-Intensity-Saturation transformation (Mather 2004). The SRTM map was used as the background in all geophysical maps in order to help interpretation.

A kernel density algorithm developed by Silverman (1986) was used in the computation of the lineament density map (Fig. 5). This map shows the number of lineaments per unit area and indicates areas of increased bedrock fracturing. It allows identification of regions with high fault density and areas

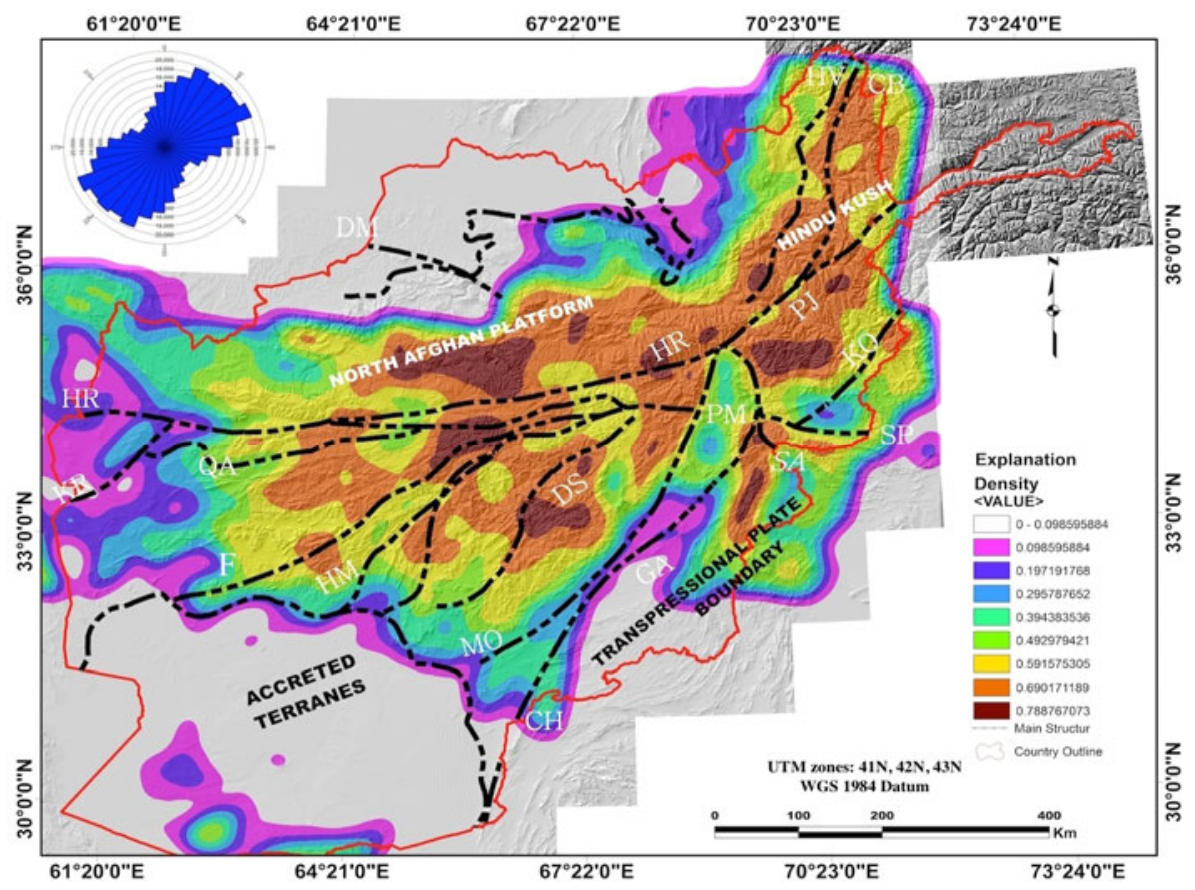

Fig. 5. Automated satellite lineaments density map in Afghanistan, overlaid on the shaded relief (SRTM) map. 
lacking faults/joints. To obtain a density map, a grid structure is defined and each linear structure (lineament) that is at least partially within a grid cell is counted toward the total number of lineaments in that grid cell. The density map for Afghanistan was compiled from the digital lineaments extracted from the Landsat imagery and from the shaded relief SRTM. The density map was computed from all lineaments as well as by selecting lineaments within the specific orientation groups determined in each section. Interpreted lineaments occur mainly in the three directions NNE-SSW, NE-SW, and ENE-WSE (Fig. 5), which are the directions of the major faults, $\mathrm{CH}, \mathrm{HM}$, and HR, respectively.

\section{POTENTIAL FIELD DATA}

The study of regional gravity and magnetic anomalies has a long and distinguished history of geological and structural investigations of the Earth's lithosphere (Hinze 1985, Aitken and Betts 2009, Jessell et al. 2012, Stewart and Betts 2010). The magnetic dataset is derived from 2006 aeromagnetic

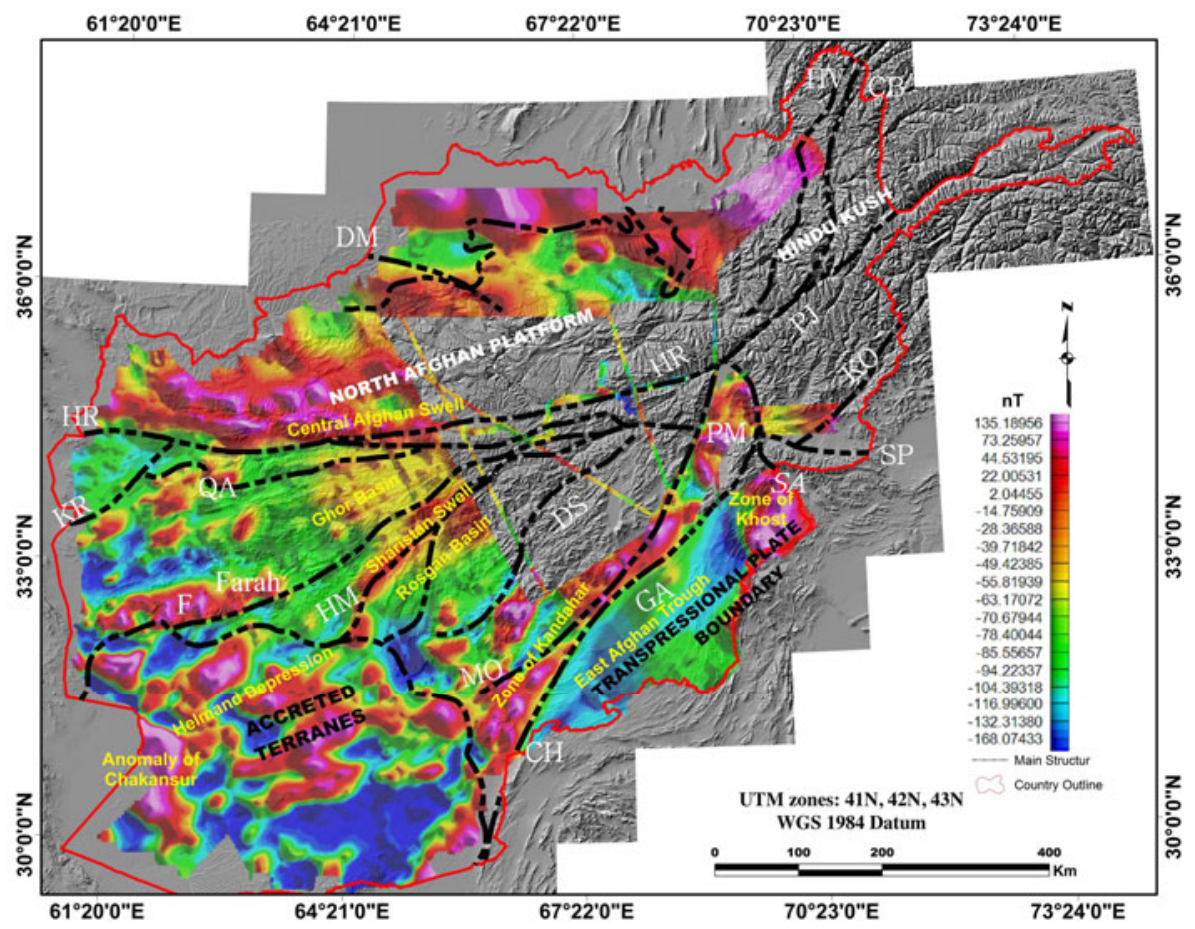

Fig. 6. Reduced-to-pole magnetic map of Afghanistan, overlaid on the shaded relief (SRTM) map. The yellow text shows the major geological and morphological divisions in connection with the magnetic anomalies. 


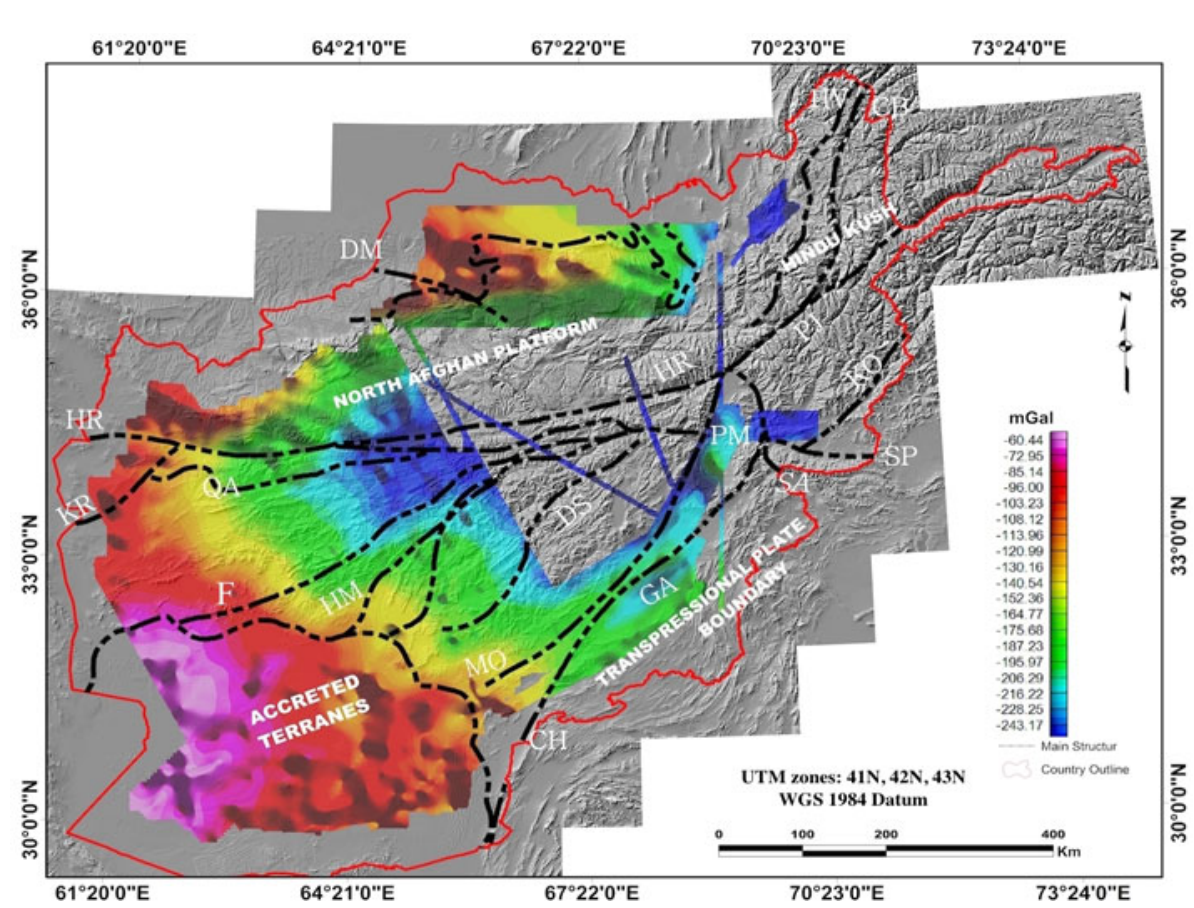

Fig. 7. Complete Bouguer gravity map of Afghanistan, overlaid on the shaded relief (SRTM) map.

surveys provided by U.S. Geological Survey and the grid elevation is $5000 \mathrm{~m}$ above terrain (USGS 2006). Five base station magnetometers were used during the survey. In order to correct the airborne magnetic data for time-varying anomalies, a weighted average of data from the five base stations was used to predict the time-varying field at the aircraft (USGS 2011). To overcome bi-polarity related problems, the total magnetic intensity data are gridded by minimum curvature method (with a grid size of $1000 \mathrm{~m}$ ) and then reduced to the pole (RTP) using a magnetic inclination of 48.74 and a declination of 2.01 degrees. Magnetic data ranges from -168 to $650 \mathrm{nT}$ (Fig. 6).

The gravity dataset comprises ground gravity data collected during 1966 and 1967 by the Afghanistan Water and Soil Survey Authority (McGinnis 1971) and airborne gravity data collected by the USGS in 2006 and 2008 (USGS 2006, 2008). The observed gravity data were corrected by the USGS prior to our utilization. Both data were combined to form the complete Bouguer gravity map of Afghanistan (Fig. 7).

The airborne potential field data do not cover eastern Afghanistan (high topography region). 


\section{POTENTIAL FIELD INTERPRETATION METHODS}

\subsection{Power spectrum analysis}

A power spectral analysis yielded information on the depth of a significant density contrast in the crust and on the crustal structure (Gotze and Krause 2002). Saibi et al. (2012) applied successfully this method for estimating gravity source depths. Spector and Bhattacharyya (1966) studied the energy spectrum, which was calculated from different 3D model configurations. Spector and Grant (1970) studied the statistical ensemble of 3D maps and concluded a general form of the spectrum

$$
E(r, \vartheta)=\langle H(h, r)\rangle\langle S(a, b, r, \vartheta)\rangle\langle C(t, \Phi, r)\rangle,
$$

where $E$ is the energy spectral density (energy per Hz), $r$ the radial wave number (cycles per distance unit), $\vartheta$ the azimuth of radial wave number (degree), \langle\rangle expresses the ensemble average, $h$ the depth (in meters); $H$ the depth factor, $S$ the horizontal size (width) factor, $C$ the vertical size (thickness or depth extent) factor, $a$ and $b$ the parameters related to the horizontal dimensions of the sources, $t$ and $\Phi$ the parameters related to the vertical depth extent of the source.

Only three factors $(H, S$, and $C)$ are functions of the radial frequency $r$; thus, in the azimuthally averaged profile form, Eq. 1 can be written as:

$$
\ln E(q)=\ln H\left(h^{*}, q\right)+\ln S\left(a^{*}, q\right)+\ln C\left(t^{*}, \Phi, q\right)+\text { constant },
$$

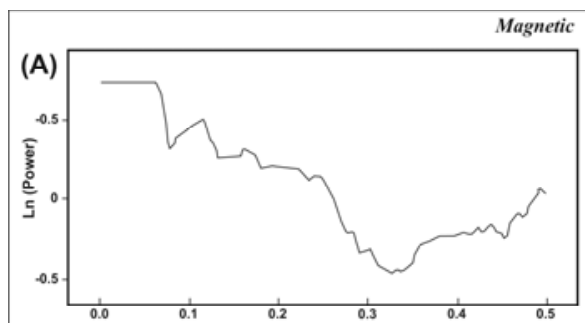

(B)


Fig. 8: Left: (A) Azimuthally averaged power spectrum of the RTP magnetic data of Afghanistan, (B) magnetic source depth estimation based on linear segments of the energy decay curve; Right: (A) Azimuthally averaged power spectrum of the complete Bouguer gravity data of Afghanistan, (B) gravity source depth estimation based on linear segments of the energy decay curve. 
where $h^{*}, a^{*}, t^{*}$ are the average depth, half width and thickness of the source ensemble, respectively.

This equation demonstrates that contributions from the depths to the top of layers, widths and thicknesses of the source ensemble can affect the shape of the energy spectral decay curve. Figure 8 (right) shows the averaged power density spectrum of the gravity data of Afghanistan and the instantaneous depths of the gravity sources. Two different gravity contributions can be seen: a deep-seated source at a depth of around 2 to $2.5 \mathrm{~km}$, and a shallow source at a depth of 1 to $1.5 \mathrm{~km}$. Figure 8 (left) shows the averaged power density spectrum of the magnetic data of Afghanistan and the instantaneous depths of the magnetic sources. Two different magnetic contributions can be seen: a deep-seated source at a depth of around $3.8 \mathrm{~km}$, and a shallow source at a depth of 1 to $1.5 \mathrm{~km}$.

\subsection{Analytic signal method (AS)}

The AS method (Nabighian 1972), also called the total gradient method, has been the subject of continuing investigation and improvements since it was first applied (e.g., Nabighian 1974, 1984; Roest et al. 1992, MacLeod et al. 1993, Hsu et al. 1996, 1998; Debeglia and Corpel 1997, Keating and Pilkington 2004). Roest et al. (1992) showed that the amplitude (absolute value) of the 3D analytic signal at location $(x, y)$ can be easily derived from the three orthogonal gradients of the total magnetic field. In the analytic signal method, it is assumed that the causative sources are magnetic contacts.

Their counterparts, in the case of gravity data, have been introduced by Klingele et al. (1991). The general equation for a 3D source is:

$$
\operatorname{AS}(x, y)=\operatorname{SQRT}\left\{(\partial F / \partial x)^{2}+(\partial F / \partial y)^{2}+(\partial F / \partial z)^{2}\right\},
$$

where $\operatorname{AS}(x, y)$ is the amplitude of the analytic signal at $(x, y), F$ is the potential field observed at $(x, y)$, and $(\partial F / \partial x),(\partial F / \partial y),(\partial F / \partial z)$ are the two horizontal and vertical derivatives of the potential field, respectively.

The maxima of AS is very useful for delineating edges of magnetic sources because of the amplitude of the AS peaks over magnetic sources. The maxima of AS of the magnetic data produce clear resolution of the shallower bodies, but do not delineate the deeper body very well (Arisoy and Dikmen 2013). The analytic signal signature of Afghanistan was calculated (Figs. 9 and 10) in the frequency domain using the fast Fourier transform technique (Blakely 1995). Higher values of the analytic signal of magnetic data are observed mainly in the accreted terranes area and along the HR and $\mathrm{CH}$ faults (Fig. 9), indicating that these regions have significant magnetic susceptibility contrasts that produce identifiable signatures on the map. 




Fig. 9. Analytic signal map of magnetic data of Afghanistan, overlaid on the shaded relief (SRTM) map.

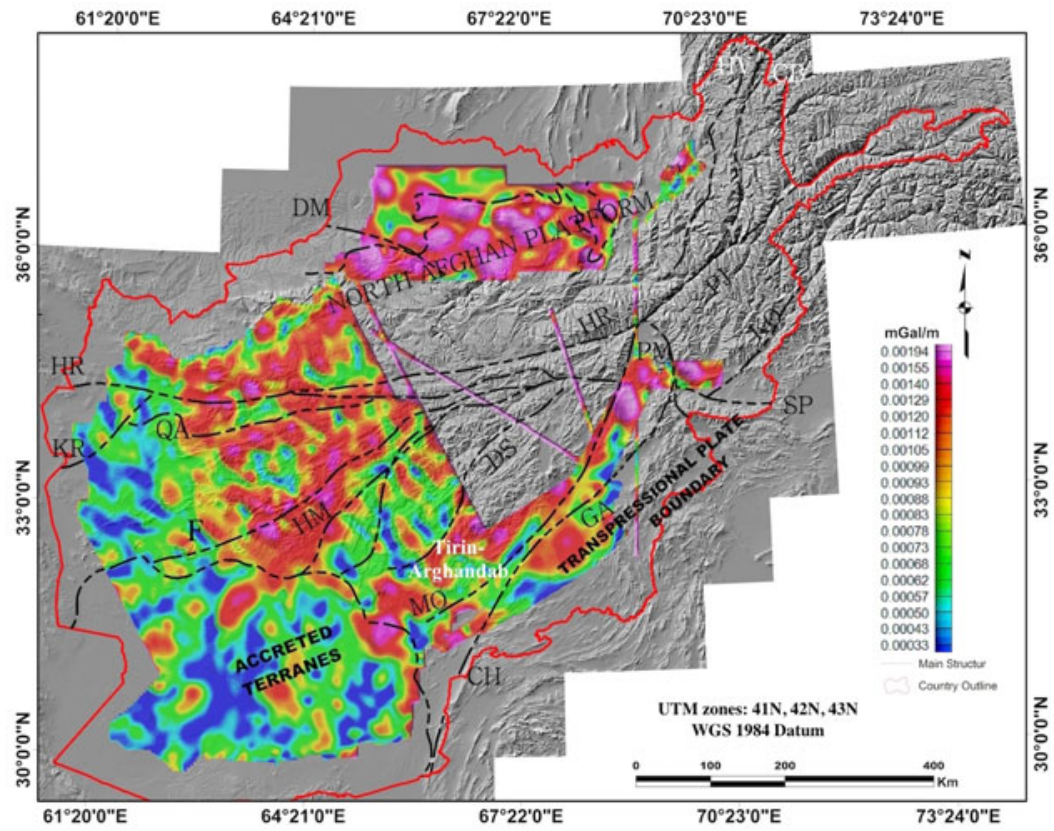

Fig. 10. Analytic signal map of gravity data of Afghanistan, overlaid on the shaded relief (SRTM) map. 
High analytic signal of gravity data is observed on the north Afghan platform (Fig. 10) and also along HR and HM fault structures and in the TirinArghandab zone.

\subsection{Tilt derivative method (TDR)}

The tilt derivative method, also called tilt angle method, is a refinement of the analytic signal method suggested by Miller and Singh (1994) and by Verduzco et al. (2004). The TDR determines the location and depth of vertical magnetic contacts without prior information on the source configuration by using the horizontal gradient amplitude (first horizontal derivative) of the tilt angle. The method has been further developed by Salem et al. (2007, 2008) and Fairhead et al. (2008). The TDR method was used to enhance and sharpen the potential field anomalies. The advantage of TDR is that it can show the zero contour line located on or close to a contact. The TDR is defined as:

$$
\operatorname{TDR}=\tan ^{-1}\left\{(\partial F / \partial z) / \operatorname{SQRT}\left[(\partial F / \partial x)^{2}+(\partial F / \partial y)^{2}\right]\right\},
$$

where $F$ is the potential field observed at $(x, y)$, and $(\partial F / \partial x),(\partial F / \partial y),(\partial F / \partial z)$ are the two horizontal and vertical derivatives of the potential field, respec-

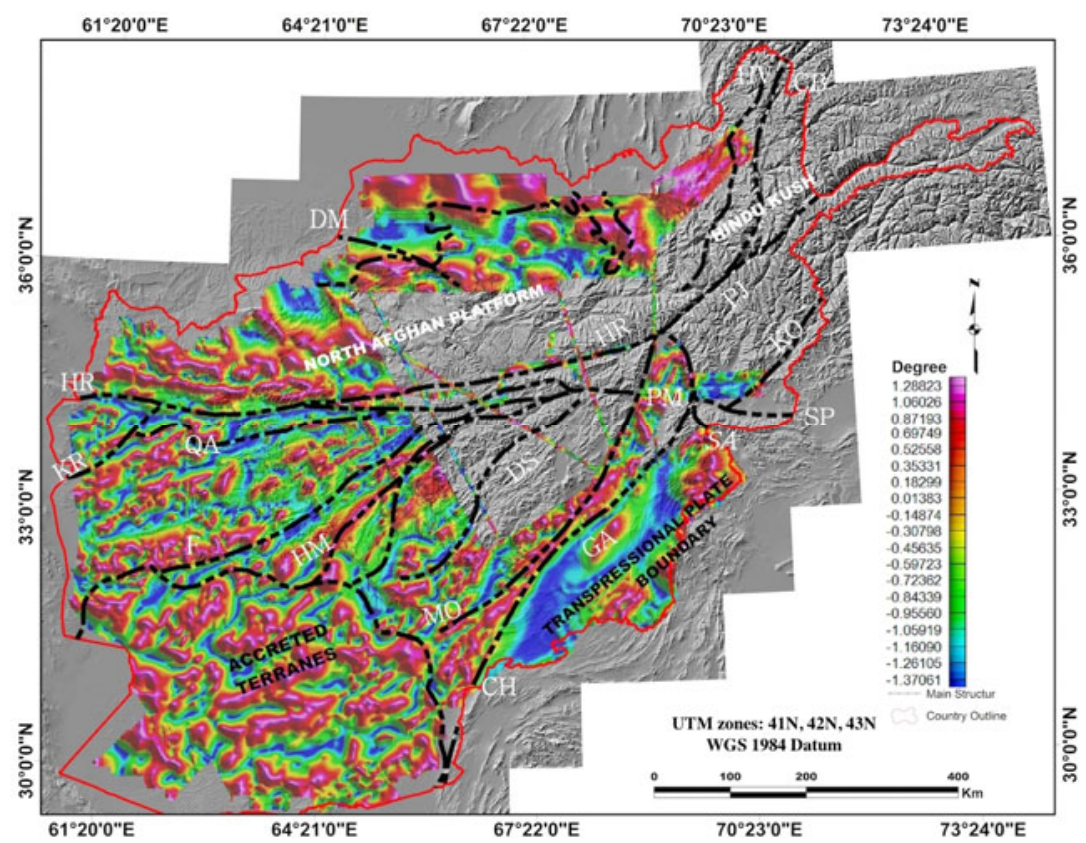

Fig. 11. Tilt derivative map of magnetic data of Afghanistan, overlaid on the shaded relief (SRTM) map. 




Fig. 12. Tilt derivative map of gravity data of Afghanistan, overlaid on the shaded relief (SRTM) map.

tively. The TDR method has the advantage of responding well to both shallow and deep sources, and the map of TDR recognizes the horizontal location and extent of sources. The TDR of magnetic and gravity data are presented in Figs. 11 and 12, respectively. The TDR has enhanced the potential field anomalies considerably compared to the original maps of magnetic and gravity.

\subsection{Horizontal gradient of the tilt derivative method (HG-TDR)}

Verduzco et al. (2004) presented an edge detector, which is the horizontal derivative of the tilt derivative:

$$
\mathrm{HG}-\mathrm{TDR}=\operatorname{SQRT}\left\{(\partial(\mathrm{TDR}) / \partial x)^{2}+(\partial(\mathrm{TDR}) / \partial y)^{2}\right\} .
$$

HG-TDR is independent of the geomagnetic field and generates maximum values over the edges of the magnetized bodies. Figures 13 and 14 show the HG-TDR of the magnetic and gravity data, respectively. The HGTDR delineates model edges well, as the amplitude of the HG-TDR peaks over magnetic sources, but the results for the deeper bodies are not so effective (Arisoy and Dikmen 2013). 




Fig. 13. Horizontal gradient of the tilt derivative map of magnetic data of Afghanistan, overlaid on the shaded relief (SRTM) map.

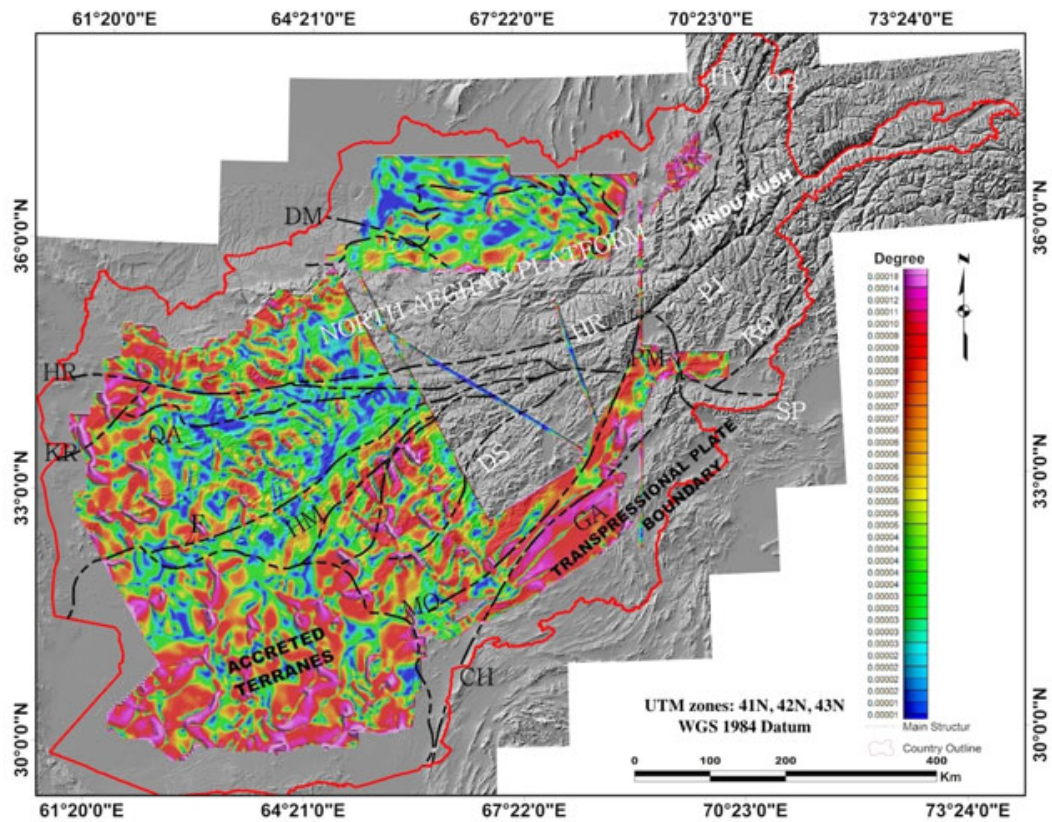

Fig. 14. Horizontal gradient of the tilt derivative map of gravity data of Afghanistan, overlaid on the shaded relief (SRTM) map. 


\subsection{Euler deconvolution method (ED)}

The ED is used to estimate the depth and location of magnetic source anomalies. The computerized method was developed by Thompson (1982) and is applied for real magnetic data along profiles. Reid et al. (1990) followed up a suggestion in Thompson's paper and further developed the method such that it operates for magnetic grid data. The original technique was referred to as the EULDPH method, but with further development, it has become known as the extended ED technique (Mashayandebvu et al. 2001). The significant advantage of this method is that the results are independent of the direction of magnetic polarization and geologic knowledge of the source (Hinze et al. 2013).

The ED equation in 3D is given by Reid et al. (1990):

$$
(x-x o)(\partial M / \partial x)+(y-y o)(\partial M / \partial y)+(z-z o)(\partial M / \partial z)=n(B-M) .
$$

Equation 6 can be rewritten as

$$
\begin{aligned}
x(\partial M / \partial x) & +y(\partial M / \partial y)+z(\partial M / \partial z)+n M= \\
& =x o(\partial M / \partial x)+y o(\partial M / \partial y)+z o(\partial M / \partial z)+n B .
\end{aligned}
$$

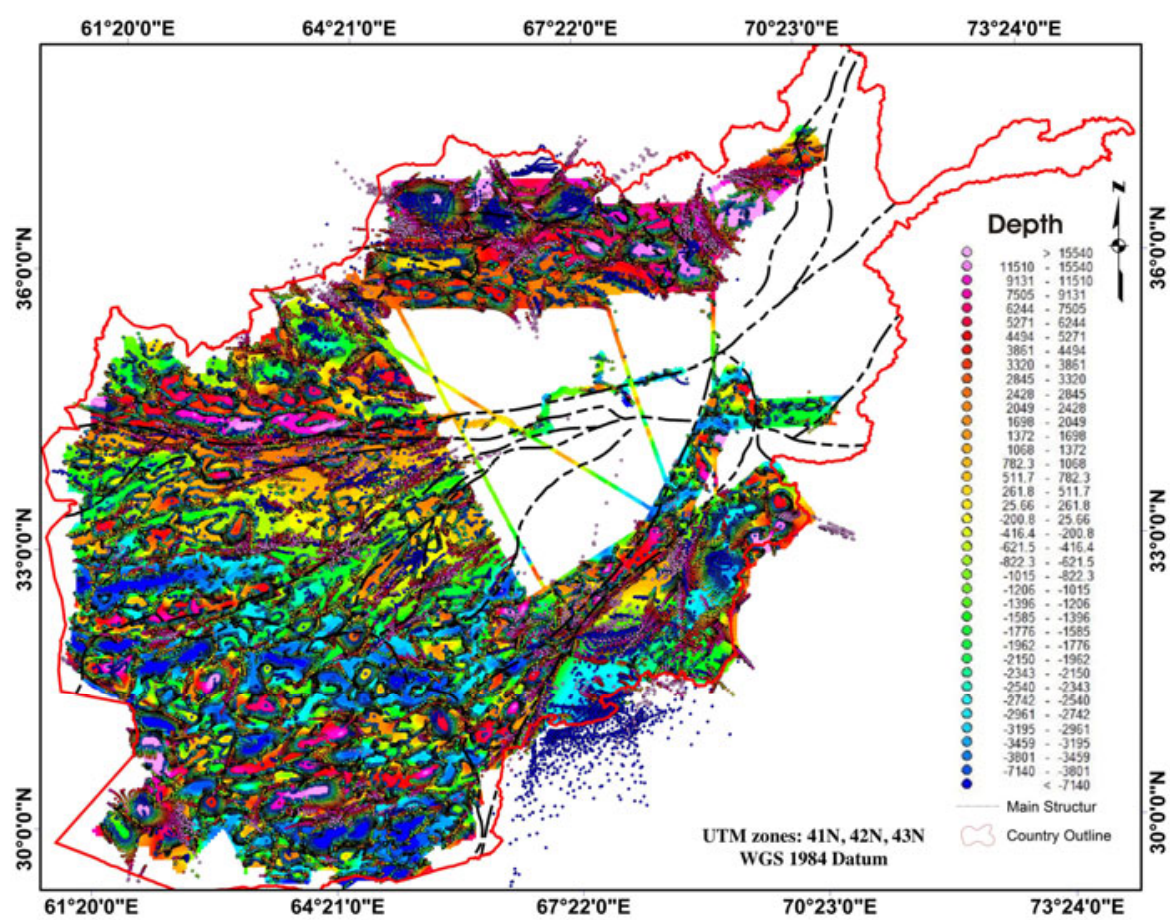

Fig. 15. Euler deconvolution map of the aeromagnetic data of Afghanistan with $\mathrm{SI}=0$. The background represents the aeromagnetic map. 
where $(x o, y o, z o)$ is the position of a source whose magnetic anomaly $(M)$ is detected at $(x, y, z), B$ is the regional value of the magnetic, and $n$ is the structural index (SI), which can be defined as the rate of attenuation of the anomaly with distance. The SI must be chosen using prior knowledge of the source geometry. For example, $\mathrm{SI}=1$ for a dike, $\mathrm{SI}=0$ for a fault and contact (FitzGerald et al. 2004). The horizontal ( $\partial M / \partial x, \partial M / \partial y)$ and vertical $(\partial M / \partial z)$ derivatives are used to compute anomalous source locations. By considering four or more neighboring observations concurrently (an operating window), the source location ( $x o, y o, z o$ ) and $B$ can be computed by solving a linear system of equations generated from Eq. 7. Then, by moving the operating window from one location to another over the anomaly, multiple solutions for the same source are obtained.

The results in Fig. 15 show the Euler solutions by applying Eq. 6 to the aeromagnetic data using a structural index of 0 for faults and contacts. The depth to the magnetic sources ranges from near-surface to $10 \mathrm{~km}$. The Euler solutions are clustered along the major faults and show many circular shapes that may correspond to intrusion bodies underground.

\section{INTERPRETATION AND DISCUSSIONS}

High magnetic anomalies are correlated with major tectonic boundaries of Afghanistan such as along $\mathrm{HR}, \mathrm{CH}, \mathrm{MO}$, and $\mathrm{HM}$ faults. Other high magnetic anomalies are located in the accreted terranes (SW Afghanistan). The qualitative analysis of the RTP magnetic map in connection with the geological and morphological divisions leads to interpretation of the following subdivisions:

\subsection{The central region}

This area starts from Kandahar to the northwest up to central Afghan Swell (see Fig. 6). It includes two sedimentary basins (Ghor Basin and Rosgan Basin) and two swell (horst) regions (Central Afghan Swell and Sharistan Swell).

The RTP magnetic map shows clearly the two basins characterised by regional low magnetic responses. The Sharistan Swell, located between the two basins, is represented by medium amplitude anomalies (around $25 \mathrm{nT}$ ), which strike NE-SW similar to that of Kandahar anomalies. This region is intruded by mafic dikes (Fig. 16). High magnetic anomalies along the Helmand Fault (HM) are interpreted to represent magnetized Archean rocks and dikes associated with accretionary terranes in the western part of Afghanistan. The magnetic anomalies in the Sharistan Swell correlates with dikes and Archean rocks (Fig. 16). To the NW, magnetic anomalies decrease in amplitude as magnetic crystalline basement in that area is increasingly cov- 
ered by the Ghor Basin. The magnetic anomalies in the Ghor and Rosgan basins differ because of the depths of the depth to the magnetic crystalline rocks. The magnetic response of crystalline basement beneath the Ghor Basin is characterised by longer wavelengths and smaller amplitudes compared with the Rosgan Basin, suggesting that the magnetic basement lies beneath a thicker sedimentary pile of the Ghor Basin. There are high magnetic anomalies in the Central Afghan Swell, reaching $170 \mathrm{nT}$. The anomalies are parallel to the HR Fault and shifted to the north.

\subsection{The southeast regions}

\subsubsection{The zone of Kandahar}

This zone is bordered in the east by the Chaman Fault, which forms the border to the southeast Afghan Trough and in the north by two successive faults, the Mokur and Darafshan faults. This subdomain is characterised by the frequent occurrence of magnetic rocks (Fig. 16), which lie beneath relatively thin sedimentary successions. Magnetic anomalies strike NE-SW. The peak amplitude is $\sim 208 \mathrm{nT}$. These magnetic anomalies are largely caused by the magnetic intrusive volcanic rocks that crop out at the surface or that are

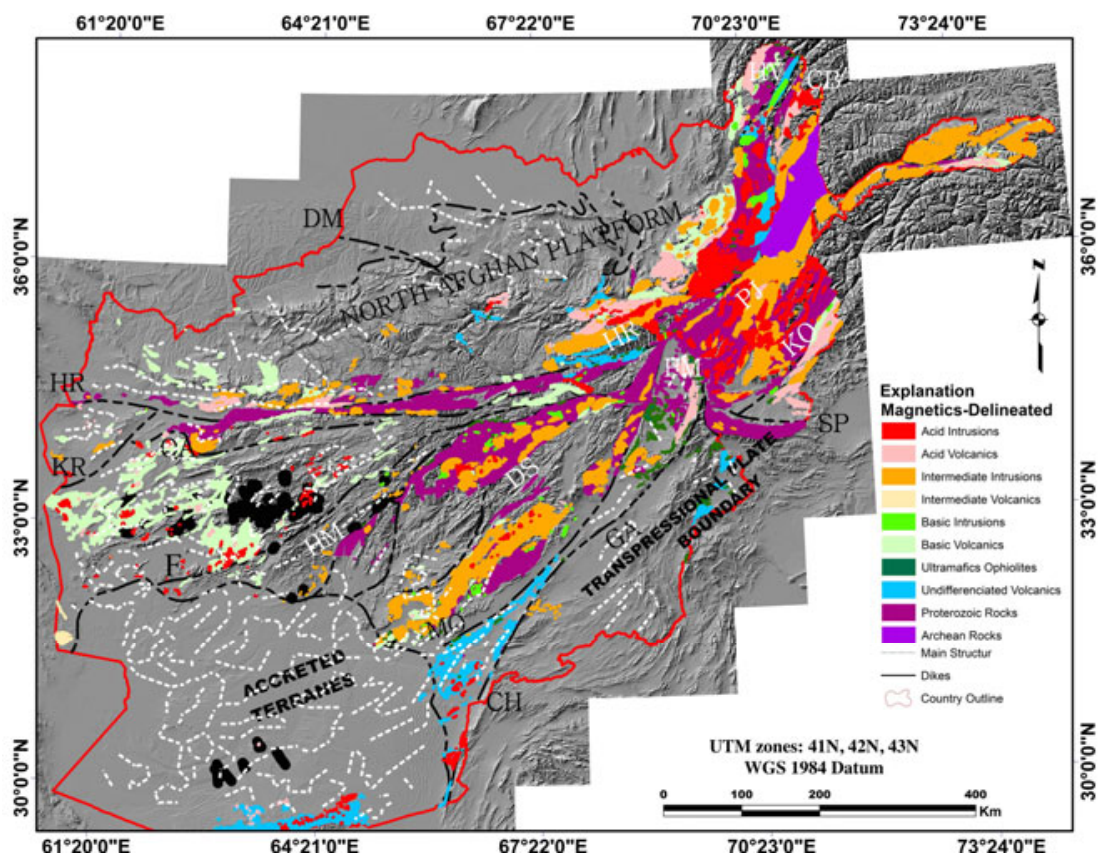

Fig. 16. Magnetic delineated units with dikes in Afghanistan, overlaid on the shaded relief (SRTM) map. White dashed lines show the interpreted fault structure from tilt derivative of aeromagnetic data. 
situated underneath a minor cover. The NE-SW magnetic anomaly of this region is parallel to the Chaman Fault.

\subsubsection{The East Afghan Trough (EAT)}

Located in the eastern part of the survey area to the east of the Chaman Fault thick Tertiary and possibly Mesozoic sedimentary successions (3 to $6 \mathrm{~km}$ ) (Bosum et al. 1968). This area is characterised by very low negative anomalies $(-165 \mathrm{nT}$ in NE and $-143 \mathrm{nT}$ in SW of EAT) to moderately low magnetic values ( -50 to $-80 \mathrm{nT}$ in $\mathrm{N}$ and SE of EAT, respectively). These anomalies are interpreted to be related to intermediate depressions and upwarpings.

\subsubsection{Zone of Khost}

This zone is located in the eastern boundary of the EAT. It is characterised by high amplitude magnetic anomalies (196 nT in the north to $460 \mathrm{nT}$ in the south), which are interpreted to be sourced from near-surface volcanic rocks (Fig. 16).

\subsection{The western regions}

The magnetic anomalies of the western regions show an entirely different character than those of the eastern regions. This region is characterized by a flat topography and existence of batholiths.

\subsubsection{Hilmand depression}

The Hilmand depression is located in the southwestern part of the survey area and consists of large deserts. This area has not been geologically explored compared to other parts of south Afghanistan due to its inaccessibility. The Hilmand depression consists of Neogene and Quaternary sediments with a thickness of around $500 \mathrm{~m}$ (Jung et al. 2013). This region has magnetic anomalies with amplitudes that range from 145 to $280 \mathrm{nT}$. These magnetic anomalies are consistent with the presence of an old block of crystalline basement rocks beneath the thin sedimentary layers. Finn and Drenth (2007) interpreted these magnetic anomalies to be related to the arc volcanic rocks within shallow crystalline basement. These volcanic rocks also exist in the northern Pakistan and eastern Iran. The low Bouguer gravity anomaly in a small region inside Helmand Basin is due to the existence of batholiths (Finn and Drenth 2007).

\subsubsection{Anomaly of Chakansur}

This region is characterised by high amplitude magnetic anomalies (see Fig. 6) that vary from $190 \mathrm{nT}$ in the south to $650 \mathrm{nT}$ in the north. The source of this high magnetic and gravity anomaly (Fig. 17) is interpreted to be a high magnetic, high density mafic intrusive body. 


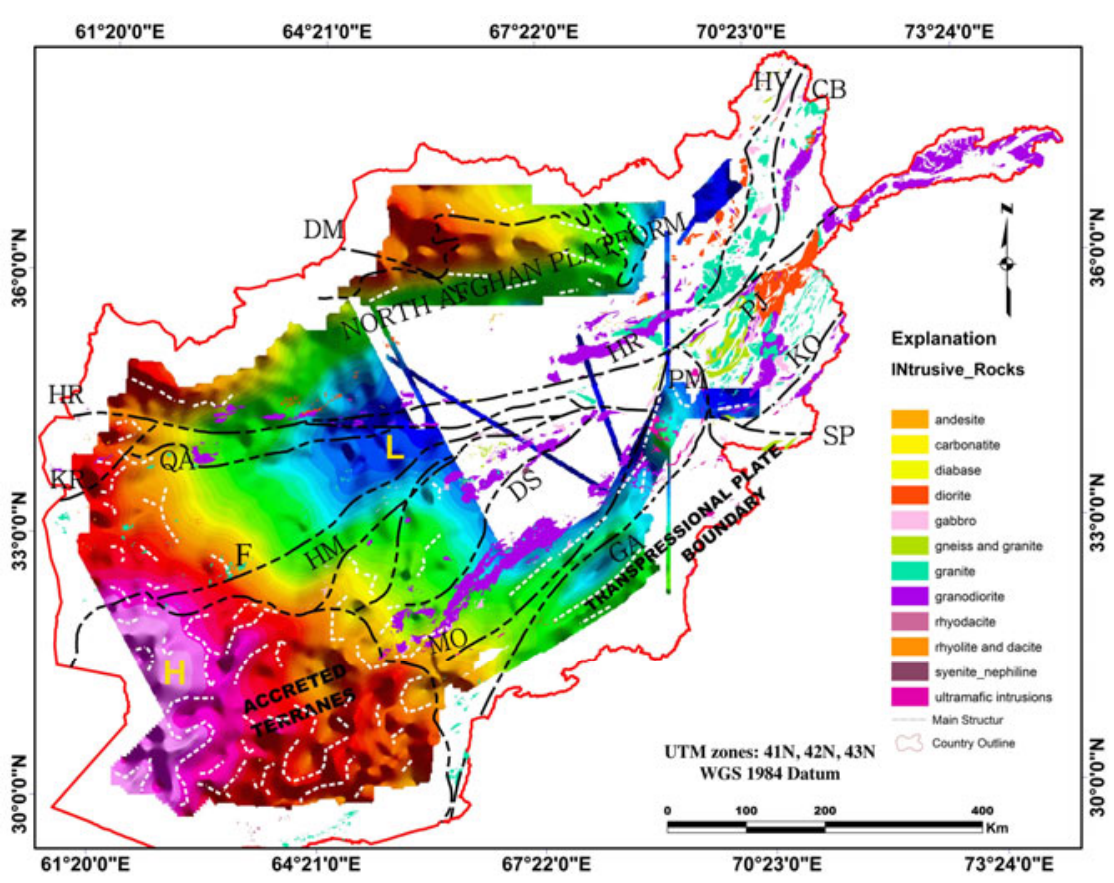

Fig. 17. High density delineated rocks in Afghanistan, overlaid on complete Bouguer gravity map. White dashed lines show the interpreted fault structure from tilt derivative of gravity data. " $\mathrm{H}$ " represents high complete Bouguer anomaly while "L" represents low complete Bouguer anomaly.

\subsubsection{Farah region}

In this region, a predominant magnetic anomaly (around $180 \mathrm{nT}$ ) striking mainly E-W extends more than $200 \mathrm{~km}$ along the Farah Fault. This region has Tertiary volcanic rocks including granites, which may cause these anomalies and possible upwarping of the magnetic basement is contributing to the magnetic response of the region.

\section{DISCUSSION}

Regional aeromagnetic data and gravity data have been effective tools for mapping inaccessible regions or terranes that are largely buried beneath younger sedimentary cover succession. We have employed analysis and interpretation of these data to characterize first order structural architecture and basement geology of a large part of the poorly understood basement geology of Afghanistan. The data has been effective at imaging major and second order faults and lineaments because they are expressed in the magnetic data as a boundary between high and low magnetic responses. The magnetic data is 
also effective at mapping the distribution of volcanic successions and intrusive rocks, which are characterised by high amplitude magnetic responses. The data also shows the extent of basement terranes beneath younger sedimentary basins, although the significance of the magnetic responses are more cryptic because anomalies are characterised by longer wavelengths and lower amplitudes because the distance to the magnetic source is greater.

Interpretation of magnetic and gravity data reveal an excellent correlation with structural architecture that has previously been related to the collision between the Indian and Eurasian plates, and thus provides a tool to assess the extent of deformation associated with this continental collision event.

\section{CONCLUSIONS}

This is the first study presenting potential field and remote sensing data of Afghanistan with the purpose of structural investigation to interpret potential field distributions in Afghanistan and the relationship with subsurface structures and geological data, supported by remote sensing information. These new investigation techniques made it possible to discover structures not yet precisely known.

The rose diagram of geological faults shows two directions: NE-SW and ENE-WSW, while the interpreted faults from remote-sensing maps show three directions: NNE-SSW, NE-SW, and ENE-WSE. The general tectonic direction of NE-SW is related to the collision tectonics of the Indian plate and the Eurasian plate. The NNE-SSW and ENE-WSW fault directions are related to the tectonics of the Arabian plate and the Eurasian plate.

The results of the power spectrum analysis of both gravity and magnetic data in Afghanistan suggest a basement depth in general at 1 to $1.5 \mathrm{~km}$, which is in agreement with the calculated sediment thickness in Afghanistan of the same range (shallow to $1 \mathrm{~km}$ ) by Jung et al. (2013).

The general trend of the Bouguer gravity anomalies is NE-SW along the Indian-Afghan collision zone, which is similar to the trend also found in western Pakistan (Jadoon and Khurshid 1996).

The high Bouguer gravity anomaly in the Helmand Basin suggests a possible existence of an intrusive volcanic body covered by late thin quaternary sediments.

Many magnetic anomalies were observed in the accreted terranes, which could be intrusions of magnetized bodies in the basement rocks. These intrusions are young volcanic rocks, which might be related to the subduction of Arabian oceanic crust beneath Eurasia.

The used data has a low resolution but could provide useful information on the subsurface structures and geological information in Afghanistan and 
also the geophysical signatures of volcanic and intrusive rocks in the country. We recommend future high resolutions geophysical surveys in Afghanistan and especially in the no-data regions (eastern parts) in order to enhance the geological, structural, and mineralogical investigations.

Acknowledgments. The authors would like to thank Dr. J.F. Batir (Southern Methodist University, Huffington Department of Earth Sciences, Dallas, USA) for suggesting a number of improvements in this manuscript. We also thank Prof. P.G. Betts (Monash University, School of Earth, Atmosphere and Environment, Australia) for his careful reading of our manuscript and numerous constructive suggestions that helped improve this paper. S. Mogren acknowledges support from the National Plan for Science, Technology and Innovation (MAARIFAH), King Abdulaziz City for Science and Technology, Kingdom of Saudi Arabia, Award Number 09-SPA873-02.

\section{References}

AGS (2005), Geology of Afghanistan, Afghanistan Geological Survey, available from: http://www.bgs.ac.uk/afghanminerals/geology.htm (accessed: 2015).

Aitken, A.R.A., and P.G. Betts (2009), Multi-scale integrated structural and aeromagnetic analysis to guide tectonic models: An example from the eastern Musgrave Province, Central Australia, Tectonophysics 476, 3-4, 418-435, DOI: 10.1016/j.tecto.2009.07.007.

Arisoy, M.O., and U. Dikmen (2013), Edge detection of magnetic sources using enhanced total horizontal derivative of the tilt angle, Bull. Earth Sci. Appl. Res. Cent. Hacet. Univ. 34, 1, 73-82.

Azizi, M., and H. Saibi (2015), Integrating gravity data with remotely sensed data for structural investigation of the Aynak-Logar Valley, eastern Afghanistan, and the surrounding area, IEEE J. Sel. Top. Appl. Earth Observ. Remote Sens. 8, 2, 816-824, DOI: 10.1109/JSTARS.2014.2347375.

Azizi, M., H. Saibi, and G.R.J. Cooper (2015), Mineral and structural mapping of the Aynak-Logar Valley (eastern Afghanistan) from hyperspectral remote sensing data and aeromagnetic data, Arab. J. Geosci. 8, 12, 10911-10918, DOI: 10.1007/s12517-015-1993-2.

Betts, P.G., R.K. Valenta, and J. Finlay (2003), Evolution of the Mount Woods Inlier, northern Gawler Craton, Southern Australia: An integrated structural and aeromagnetic analysis, Tectonophysics 366, 1-2, 83-111, DOI: 10.1016/ S0040-1951(03)00062-3.

Betts, P., H. Williams, J. Stewart, and L. Ailleres (2007), Kinematic analysis of aeromagnetic data: Looking at geophysical data in a structural context, Gondwana Res. 11, 4, 582-583. 
Blaikie, T.N., L. Ailleres, P.G. Betts, and R.A.F. Cas (2014), Interpreting subsurface volcanic structures using geologically constrained 3-D gravity inversions: Examples of maar-diatremes, Newer Volcanics Province, southeastern Australia, J. Geophys. Res. Solid Earth 119, 4, 3857-3878, DOI: 10.1002/ 2013JB010751.

Blakely, R.J. (1995), Potential Theory in Gravity and Magnetic Applications, Cambridge University Press, Cambridge, $441 \mathrm{pp}$.

Bosum, W., A. Hahn, E.G. Kind, and D. Weippert (1968), Airborne magnetometer survey in the Kingdom of Afghanistan, Geological Survey of the Federal Republic of Germany, 46 pp.

Chen, S., and Y. Zhou (2005), Classifying depth-layered geological structures on Landsat TM images by gravity data, a case study of the western slope of Songliao Basin, northeast China, Int. J. Remote Sens. 26, 13, 2741-2754, DOI: $10.1080 / 01431160500104210$.

Debeglia, N., and J. Corpel (1997), Automatic 3-D interpretation of potential field data using analytic signal derivatives, Geophysics 62, 1, 87-96, DOI: 10.1190/1.1444149.

Durga Rao, K.H.V., V. Bhanumurthy, and P.S. Roy (2009), Application of satellitebased rainfall products and SRTM DEM in hydrological modelling of Brahmaputra basin, J. Indian Soc. Remote Sens. 37, 4, 587-600, DOI: 10.1007/s12524-009-0051-5.

Fairhead, J.D., A. Salem, S. Williams, and E. Samson (2008), Magnetic interpretation made easy: The tilt-depth-dip- $\Delta k$ method. In: 2008 SEG Ann. Int. Meeting, Expanded abstracts, Society of Exploration Geophysicists, 779783.

Finn, C.A., and B. Drenth (2007), Regional gravity and magnetic data help map subsurface geology in Afghanistan. In: GSA Denver Ann. Meeeting, Abstract \# 156-9.

FitzGerald, D., A. Reid, and P. McInerney (2004), New discrimination techniques for Euler deconvolution, Comput. Geosci. 30, 5, 461-469, DOI: 10.1016/ j.cageo.2004.03.006.

Gotze, H.J., and S. Krause (2002), The Central Andean gravity high, a relic of an old subduction complex? J. South Am. Earth Sci. 14, 8, 799-811, DOI: 10.1016/S0895-9811(01)00077-3.

Hinze, W.J. (1985), The Utility of Regional Gravity and Magnetic Anomaly Maps, Society of Exploration Geophysicists, 469 pp.

Hinze, W.J., R.R.B. von Frese, and A.H. Saad (2013), Gravity and Magnetic Exploration, Cambridge University Press, Cambridge, 525 p.

Hsu, S.-K., J.-C. Sibuet, and C.-T. Shyu (1996), High resolution detection of geologic boundaries from potential field anomalies: An enhanced analytic signal technique, Geophysics 61, 2, 373-386, DOI: 10.1190/1.1443966. 
Hsu, S.-K., D. Coppens, and C.-T. Shyu (1998), Depth to magnetic source using the generalized analytic signal, Geophysics 63, 6, 1947-1957, DOI: 10.1190/ 1.1444488 .

Jadoon, I.A.K., and A. Khurshid (1996), Gravity and tectonic model across the Sulaiman fold belt and the Chaman Fault zone in western Pakistan and eastern Afghanistan, Tectonophysics 254, 1-2, 89-109, DOI: 10.1016/00401951(95)00078-X.

Jessell, M.W., P.O. Amponsah, L. Baratoux, D.K. Asiedu, G.K. Loh, and J. Ganne (2012), Crustal-scale transcurrent shearing in the Paleoproterozoic SefwiSunyani-Comoé region, West Africa, Precambrian Res. 212-213, 155-168, DOI: 10.1016/j.precamres.2012.04.015.

Jung, W., J. Brozena, and M. Peters (2013), Predicting gravity and sediment thickness in Afghanistan, Geophys. J. Int. 192, 2, 586-601, DOI: 10.1093/gji/ ggs038.

Kamel, A.F., and A.M. Elsirafe (1994), Delineation and analysis of the surface and subsurface structural lineament patterns in the North Lake Nasser area and its surroundings, Aswan, upper Egypt, Int. J. Remote Sens. 15, 7, 14711493, DOI: 10.1080/01431169408954178.

Keating, P., and M. Pilkington (2004), Euler deconvolution of the analytic signal and its application to magnetic interpretation, Geophys. Prospect. 52, 3, 165-182, DOI: 10.1111/j.1365-2478.2004.00408.x.

Khamies, A.A., and M.M. El-Tarras (2010), Surface and subsurface structures of Kalabsha area, southern Egypt, from remote sensing, aeromagnetic and gravity data, Egypt. J. Remote Sens. Space Sci. 13, 1, 43-52, DOI: 10.1016/ j.ejrs.2010.07.006.

Klingele, E.E., I. Marson, and H.G. Kahle (1991), Automatic interpretation of gravity gradiometric data in two dimensions: vertical gradient, Geophys. Prospect. 39, 3, 407-434, DOI: 10.1111/j.1365-2478.1991.tb00319.x.

Lamontagne, M., P. Keating, and S. Perreault (2003), Seismotectonic characteristics of the lower St. Lawrence seismic zone, Quebec, insights from geology, magnetics, gravity, and seismic, Can. J. Earth Sci. 40, 2, 317-336, DOI: 10.1139/e02-104.

Lunden, B., G. Wang, and K. Wester (2001), A GIS based analysis of data from Landsat TM, airborne geophysical measurements, and digital maps for geological remote sensing in the Stockholm region, Sweden, Int. J. Remote Sens. 22, 4, 517-532, DOI: 10.1080/01431160050505838.

MacLeod, I.N., K. Jones, and T.F. Dai (1993), 3-D analytic signal in the interpretation of total magnetic field data at low magnetic latitudes, Explor. Geophys. 24, 3-4, 679-688, DOI: 10.1071/EG993679.

Mashayandebvu, M., P. van Driel, A.B. Reid, and J.D. Fairhead (2001), Magnetic source parameters of two-dimensional structures using extended Euler deconvolution, Geophysics 66, 3, 814-823, DOI: 10.1190/1.1444971. 
Mather, P.M. (2004), Computer Processing of Remotely-sensed Images: An Introduction, 3rd ed., John Wiley \& Sons, Chichester, 442 pp.

McGinnis, L.D. (1971), Gravity fields and tectonics in the Hindu Kush, J. Geophys. Res. 76, 8, 1894-1904, DOI: 10.1029/JB076i008p01894.

McLean, M.A., C.J.L. Wilson, S.D. Boger, P.G. Beas, T.J. Rawling, and D. Damaske (2009), Basement interpretations from airborne magnetic and gravity data over the Lambert Rift region of East Antarctica, J. Geophys. Res. 114, B6, B06101, DOI: 10.1029/2008JB005650.

Mihalasky, M.J., J.L. Doebrich, R.W. Wahl, S.D. Ludington, G.J. Orris, J.D. Bliss, D.M. Sutphin, P.G. Schruben, K.S. Bolm, B.E. Hubbard, J.C. Mars, S.G. Peters, C.J. Wandrey, and P. Chirico (2007), Geographic information system (GIS) to accompany the non-fuel mineral resource assessment of Afghanistan. Appendix 1. In: S.G. Peters, S.D. Ludington, G.J. Orris, D.M. Sutphin, J.D. Bliss, J.J. Rytuba (eds.), Preliminary Non-fuel Mineral Resource Assessment of Afghanistan, U.S. Geological Survey - Afghanistan Ministry of Mines Joint Mineral Resource Assessment Team U.S., Geological Survey Open-File Report, 2007-1214 (Version 1), 2 CD-roms.

Miller, H.G., and V. Singh (1994), Potential field tilt - a new concept for location potential field sources, Appl. Geophys. 32, 2-3, 213-217, DOI: 10.1016/ 0926-9851(94)90022-1.

Nabighian, M.N. (1972), The analytic signal of two-dimensional magnetic bodies with polygonal cross-section: its properties and use for automated anomaly interpretation, Geophysics 37, 3, 507-517, DOI: 10.1190/1.1440276.

Nabighian, M.N. (1974), Additional comments on the analytic signal of two dimensional magnetic bodies with polygonal cross-section, Geophysics 39, 1, 8592, DOI: 10.1190/1.1440416.

Nabighian, M.N. (1984), Toward a three-dimensional automatic interpretation of potential field data via generalized Hilbert transforms: Fundamental relations, Geophysics 49, 6, 780-786, DOI: 10.1190/1.1441706.

Rabie, S.I., and A.A. Ammar (1990), Pattern of the main tectonic trends from remote geophysics, geological structures and satellite imagery, Central Eastern Desert, Egypt, Int. J. Remote Sens. 11, 4, 669-683, DOI: 10.1080/ 01431169008955049.

Reid, A.B., J.M. Allsop, H. Granser, A.J. Millett, and I.W. Somerton (1990), Magnetic interpretation in three dimensions using Euler deconvolution, Geophysics 55, 1, 80-91, DOI: 10.1190/1.1442774.

Roest, W.R., J. Verhoef, and M. Pilkington (1992), Magnetic interpretation using 3D analytic signal, Geophysics 57, 1, 116-125, DOI: 10.1190/1.1443174.

Saadi, N.M., E. Aboud, H. Saibi, and K. Watanabe (2008a), Integrating data from remote sensing, geology and gravity for geological investigation in the Tarhunah area, Northwest Libya, Int. J. Digital Earth 1, 4, 347-366, DOI: $10.1080 / 17538940802435844$. 
Saadi, N.M., K. Watanabe, A. Imai, and H. Saibi (2008b), Integrating potential fields with remote sensing data for geological investigations in the Eljufra area of Libya, Earth Planets Space 60, 6, 539-547, DOI: 10.1186/ BF03353116.

Saibi, H., E. Aboud, and S. Ehara (2012), Analysis and interpretation of gravity data from the Aluto-Langano geothermal field of Ethiopia, Acta Geophys. 60, 2, 318-336, DOI: 10.2478/s11600-011-0061-x.

Salem, A., S. Williams, J.D. Fairhead, D. Ravat, and R. Smith (2007), Tilt-depth method: A simple depth estimation method using first-order magnetic derivatives, The Leading Edge 26, 12, 1502-1505, DOI: 10.1190/1.2821934.

Salem, A., S. Williams, J.D. Faihead, R. Smith, and D. Ravat (2008), Interpretation of magnetic data using tilt-angle derivatives, Geophysics 73, 1, L1-L10, DOI: 10.1190/1.2799992.

Schindler, J.S. (2002), Afghanistan: Geology in a troubled land, Geotimes 47, 2, 14-15.

Silverman, B.W. (1986), Density Estimation for Statistics and Data Analysis, Monographs on Statistics and Applied Probability, Vol. 26, Chapman \& Hall/CRC, New York, 176 pp.

Spampinato, G.P.T., L. Ailleres, P.G. Betts, R.J. Armit (2015), Imaging the basement architecture across the Cork Fault in Queensland using magnetic and gravity data, Precambrian Res. 264, 63-81, DOI: 10.1016/j.precamres. 2015.04.002.

Spector, A., and F.E. Grant (1970), Statistical models for interpreting aeromagnetic data, Geophysics 35, 2, 293-302, DOI: 10.1190/1.1440092.

Spector, A., and B.K. Bhattacharyya (1966), Energy density spectrum and autocorrelation function of anomalies due to simple magnetic models, Geophys. Prospect. 14, 3, 242-272, DOI: 10.1111/j.1365-2478.1966.tb01760.x.

Stewart, J.R., and P.G. Betts (2010), Implications for Proterozoic plate margin evolution from geophysical analysis and crustal-scale modeling within the western Gawler Craton, Australia, Tectonophysics 483, 1-2, 151-177, DOI: 10.1016/j.tecto.2009.11.016.

Thompson, D.T. (1982), EULDPH: A new technique for making computer assisted depth estimates from magnetic data, Geophysics 47, 1, 31-37, DOI: 10.1190/1.1441278.

USGS (2006), Aeromagnetic and gravity surveys in Afghanistan: A website for distribution of data, U.S. Geological Survey Open-File Report, 2006-1204.

USGS (2008), Airborne gravity survey and ground gravity in Afghanistan: A website for distribution of data, U.S. Geological Survey Open-File Report, 2008-1089.

USGS (2011), Aeromagnetic surveys in Afghanistan: An updated website for distribution of data, U.S. Geological Survey Open-File Report, 2011-1247. 
Verduzco, B., J.D. Fairhead, C.M. Green, and C. MacKenzie (2004), New insights into magnetic derivatives for structural mapping, The Leading Edge 23, 116-119.

Wheeler, R., C.G. Bufe, M.L. Johnson, and R.L. Dart (2005), Seismotectonic map of Afghanistan, with annotated bibliography, U.S.G.S. Open-File Report, 2005-1264.

Yassaghi, A. (2006), Integration of Landsat imagery interpretation and geomagnetic data on verification of deep-seated transverse fault lineaments in SE Zagros, Iran, Int. J. Remote Sens. 27, 20, 4529-4544, DOI: 10.1080/ 01431160600661283 .

Received 24 December 2014

Received in revised form 22 June 2015

Accepted 26 August 2015 